\title{
1920 VE 1950 YILLARI ARASINDA MODERN GITAR MÜZiĞiNE YÖN VEREN BESTECiLER ${ }^{* *}$
}

\author{
Arş. Gör. Emre ÜNLENEN*
}

\section{ÖZET}

Andres Segovia'nın etkisiyle büyük bir sıçrama yaşayan gitar repertuvarı, 20. yüzyılın ilk yarısında, daha önce sahip olduğu repertuvardan oldukça farklı bir üsluba sahip olan gitarist olmayan bestecilerin eserleriyle şekillenmiştir. Bu çalışmada, gitar müziğinde yeni-romantik üslubun temsilcileri olarak görülebilecek Manuel Ponce, Joaquin Turina, Federico Moreno Torroba, Manuel de Falla, Heitor Villa Lobos, Mario Castelnuovo-Tedesco, Joaquin Rodrigo ve Alexandre Tansman gibi bestecilerin seçilmiş olanlarının genel bestecilik özelliklerine ve önemli eserlerine değinilecek, yapılan betimsel analizlerle örnekler verilecektir. Özellikle 1950 yılı sonrasında ortaya çıkan gitarist - modern gitar müziği bestecileri öncesinde gitar müziğinin yaşandiğı atmosfer hakkında bilgi verilmeye çalışılacaktır.

Anahtar Kelime: Segovia Etkisi, Yeni Romantik Besteciler, 1920 - 1950 yılları arası Gitar Müziği, Gitar Repertuvarı

* Anadolu Üniversitesi, Devlet Konservatuvarl, Müzik Bölümü, Eskişehir / TÜRKİYE

** Mart 2016'da Anadolu Üniversitesi Güzel Sanatlar Enstitüsu tarafından kabul edilen "Leo Brouwer’in Seçilmiş Konçertoları Üzerine Yapılan Detayl İncelemeler Işı̆̆ııda, Bestecinin Gitar Müziğine Katkılarının Değerlendirilmesi” adlı tezden alınmıştır. 


\title{
THE COMPOSERS WHO GAVE A DIRECTION TO THE MODERN GUITAR MUSIC BETWEEN 1920 AND 1950**
}

\author{
Res. Assist. Emre ÜNLENEN*
}

\section{ABSTRACT}

The guitar repertory which had a substantial spring through the impact of Andres Segovia was shaped with the works by non-guitarist composers in the first half of 20th century, which is not usual fashion as beforehand. In this study, there will be some descriptive analysis of the general features and the works of some selected composers who are considered to be the respresentatives of neo-romantic guitar music, namely Manuel Ponce, Joaquin Turina, Federico Moreno Torroba, Manuel de Falla, Heitor Villa Lobos, Mario Castelnuovo-Tedesco, Joaquin Rodrigo and Alexandre Tansman. It also aims at giving information about the atmosphere seen especially after 1950 when the guitar music is subsisted before the guitarist - modern guitar music composers.

Key words: Segovia Effect, Neo-romantic composers, guitar music between 1920 1950, Guitar Repertory

\footnotetext{
* Anadolu University, School of Music and Drama, Department of Music, Eskişehir / TURKEY emreunlenen@anadolu.edu.tr

${ }^{*}$ This article is based on a section of the dissertation named as "An Evaluation Study on Leo Brouwer's Contributions to the Guitar Music Through Comprehensive Analyses on Selected Concertos of the Composer", accepted by Anadolu University, Fine Arts Institute in March 2016
} 


\section{Gíriş}

Klasik gitar müziğinin günümüze kadarki tarihsel gelişimi incelendiğinde, İspanyol gitarist Andres Segoviảnın girişimleriyle, 1920 ve 1950 yılları arasında yeni romantik üslupta eserler veren bestecilerin repertuvara kazandırdıkları eserler önemli bir kilometre taşı olarak görülebilir. Niteliksel anlamda klasik gitarın alışılageldik sınırlarını yeniden yapılandıran bu eserler, 20. Yüzyılın başından itibaren gitarın bir klasik müzik çalgısı olarak anılmasında ve günümüzdeki popülaritesini kazanmasında etkin rol üstlenmişlerdir.

Segovia öncesinde sadece gitarist kökenli bestecilerin eser verdiği ve büyük ölçekte İspanyol Müziği hegemonyası altında olan gitar müziği, 1920 sonrasında gitarist olmayan ve daha çok senfonik eserler veren bestecilerin katkılarıyla, büyük form ölçekli, melodik ve armonik açıdan zenginleştirilmiş eserlerle genişlemiştir. Ağırlıklı olarak sonat, pedagojik eser ve konçerto formlarında bestelenen bu eserler, 20. Yüzyıl modern gitar repertuvarının temeli oluşturmuş, gitar eğitiminin Segoviảnın çalışmaları doğrultusunda ilk kez kurumsallaşmasıyla, konservatuvar eğitimi almış yeni gitarist neslinin kaynakçasını oluşturmuştur.

\section{0 Öncesi Gitar Müziğine Genel Bir Bakış}

1920 sonrasında yapılan çalışmaların gitar müziği üzerindeki etkisini doğru analiz edebilmek için, 19. Yüzyılın son yarısında gitar repertuvarının sahip olduğu eserleri değerlendirmek doğru olacaktır. Andres Segovia’nın gitar müziğine yeni bir kimlik kazandırmak için yaptığ çalışmalar, kendisinden önceki yapılan çalışmalarda tespit ettiği eksikliklere dayanmaktadır.

Günümüzde kullanılan gitarın ilk örneği olarak görülen 1852 yapımı Antonio Torres gitarlarından sonra yazılan eserler, klasik dönem gitar repertuvarı ile karşılaştırıldığında, teknik ve müzikal açıdan daha zengin ve tatmin edici olarak tanımlanabilir. Çalgının ses kapasitesinde yapılan iyileştirici çalı̧̧malarla birlikte dönemin önemli İspanyol gitarist ve bestecileri Julian Arcas, Francisco Tarrega, Daniel Fortea ve Miguel Llobet eserlerini Torres Gitarı için bestelemişlerdir. Her ne kadar bu bestecilerin verdiği eserler gitarın daha geniş kitlelerce kullanılmasına önemli katkılar sağlamış olsa da, 20. Yüzyıl Gitar Müziği düşünüldüğünde, gitarın günümüzdeki eğitim fırsatları ve yaygın kullanımı, Andres Segovia’nın kariyeri boyunca gerçekleştirmek için uğraştı̆̆ amaçları doğrultusunda şekillenmiştir.

Özellikle 19. yüzyılın başında Mauro Giuliani, Fernando Sor, Ferdinando Carulli ve Matteo Carcassi gibi döneminin önemli gitarist ve gitar bestecilerinin oluşturduğu klasik dönem repertuvarının akabinde, romantik dönem üslubunun ön plana çıkardığı melodik gelişime ve karmaşık modülasyonlarla birlikte genişlemiş form özellikli eserler gitar müziğinde sıklıkla görülmemektedir. Her ne kadar 1830 ve 1860 arasında Napoleon Coste, Luigi Legnani, Giulio Regondi ve aynı zamanda piyanist olan Johann Kaspar Mertz gibi isimlerin bıraktığı eserler özellikle form açısından daha serbest yapılarda olsalar da, klasik dönem eserlerinde sıklıkla görülen sade armoni ve modülasyonlarla, gitar çalgısının rahatlıkla kullandığı 4 diyeze ve 2 bemole kadar olan tonal alanlarda şekillendirilmiş eserlerdir. 
1850 sonrasında Julian Arcas ve akabinde Francisco Tarrega ile belirginleşen İspanyol ekolü de benzer armonik özellikli eserler vermiş ve daha çok folklorik materyaller üzerine kurgulanan eserleriyle genellikle ABA şarkı formunda ortaya çıkmışlardır. Bu nedenle, 19. Yüzyılın ortasından itibaren klasik müzikte görülen romantik üslubun gitar müziğinde tam olarak karşılığını bulamadığını söylemek mümkündür. Bu olgunun bir nedeni olarak gitar için eser veren bestecilerin aynı zamanda gitarist olmasıyla herhangi bir müzikal fikrin gitara uygulanışında belirli kalıp fikirlerle eserlerini besteledikleri çıkarımını yapmak olasıdır.

Tablo 1'de klasik müziğin ve gitar müziğinin tarihsel gelişiminde rol alan bazı önemli bestecilere değinilerek, bu iki müzik olgusunun birbiriyle etkileşimi ve gitar müziğinin geçirmiş oldu-

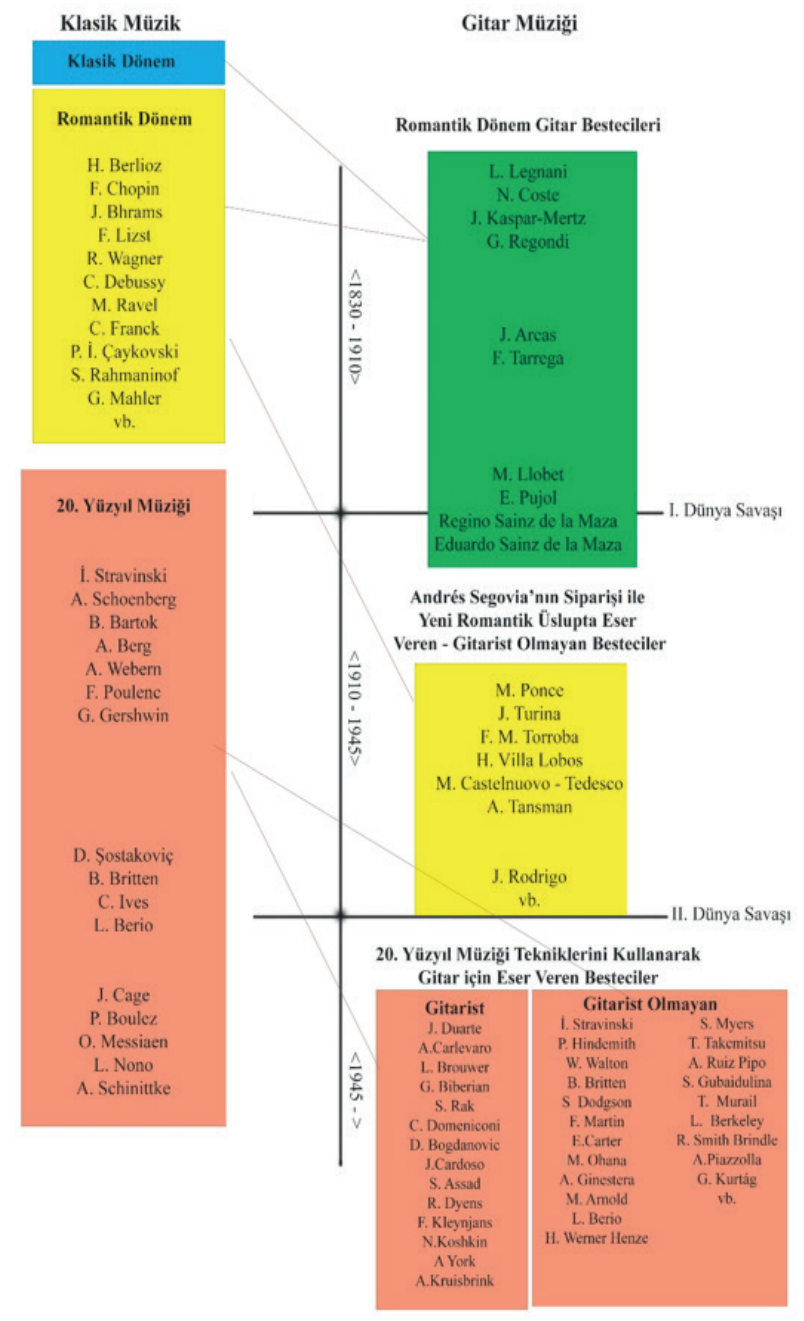

Tablo 1. Klasik müziğin ve gitar müziğinin tarihsel süreçteki etkileşimleri 


\section{0 ve 1950 Yılları Arasında Gitar Müziği için Eser Veren Besteciler}

20. yüzyılda gitar için eserler veren bestecileri farklı başlıklar altında incelemek doğru olacaktır. Bu çalışmada kategoriler, 1950 öncesi ve 1950 sonrası olmak üzere iki ana grup altında, bestecilerin bestecilik kimlikleri haricinde gitar yorumcusu olup olmamalarına, temsil ettikleri akımlara ve bestecileri gitar için yazmaya teşvik eden kişilere bakılarak oluşturulmuştur. $\mathrm{Bu}$ listelere birçok isim eklenebilecek olup, seçilen besteciler, gitar dünyasına yaptıkları katkılar göz önünde bulundurularak değerlendirilmiştir. Çalışmanın odağı 1950 öncesindeki gitar müziği çalışmalarının repertuvara katkıları olacaktır.

1890 sonrasında İspanyol gitaristler Antonio Jiménez Manjón ve Miguel Llobet’in gerçekleştirdikleri Güney Amerika turneleriyle gelişimini hızlandıran Latin gitar müziği edebiyatı, Latin gitar müziği bestecileri olarak ayrı bir kategori olarak sınıflandırılmıştır. Bu besteciler kompozisyon özelliklerindeki folklorik tabanlı armoni ve form kullanımları nedeniyle bu çalışmada değerlendirme dışında tutulmuştur. 1950 sonrası eser veren besteciler de Tablo l'de verilen gitarın tarhisel gelişimindeki yeri nedeniyle listelenmiş ve başka bir çalışmada detaylı olarak incelenecektir.

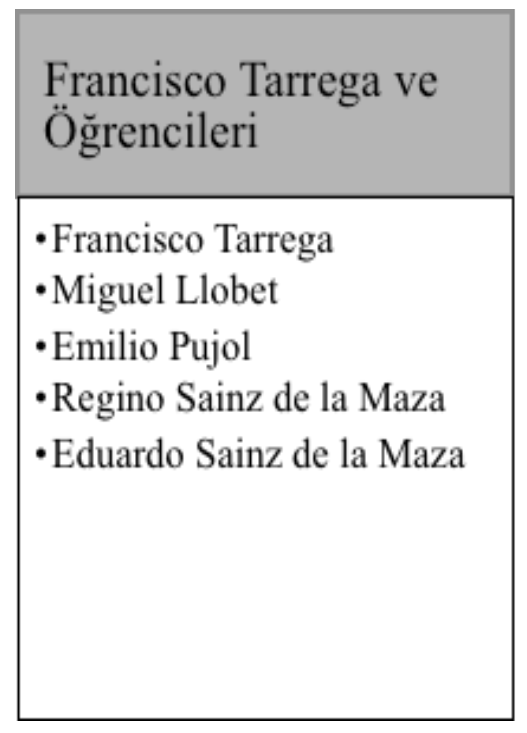

Andres Segovia'ya İthaf Eser Yazan Besteciler

- Manuel Ponce

- Joaquin Turina

- Federico Moreno Torroba

- Manuel de Falla

-Heitor Villa Lobos

- Mario Castelnuovo-

Tedesco

- Joaquin Rodrigo

- Alexandre Tansman

Görsel 1. 1950 öncesi eser veren besteciler 


\begin{tabular}{|c|c|}
\hline Gitarist Besteciler & $\begin{array}{c}\text { Gitarist Olmayan } \\
\text { Besteciler }\end{array}$ \\
\hline $\begin{array}{l}\text { - John William Duarte } \\
\text { - Abel Carlevaro } \\
\text { - Leo Brouwer } \\
\text { - Gilbert Biberian } \\
\text { - Stephan Rak } \\
\text { - Carlo Domeniconi } \\
\text { - Dusan Bogdanovic } \\
\text { - Jorge Cardoso } \\
\text { - Sergio Assad } \\
\text { - Roland Dyens } \\
\text { - Francis Kleynjans } \\
\text { - Nikita Koshkin } \\
\text { - Andrew York } \\
\text {-Annette Kruisbrink }\end{array}$ & $\begin{array}{l}\text { - Igor Stravinski } \\
\text { - Arnold Schonberg } \\
\text { - Anton Webern } \\
\text { - Paul Hindemith } \\
\text { - William Walton } \\
\text { - Benjamin Britten } \\
\text { - Stephan Dodgson } \\
\text { - Frank Martin } \\
\text { - Eliot Carter } \\
\text { - Maurice Ohana } \\
\text { - Alberto Ginestera } \\
\text { - Malcolm Arnold } \\
\text { - Lucio Berio } \\
\text { - Hans Werner Henze } \\
\text { - Stanley Myers } \\
\text { - Toru Takemitsu } \\
\text { - Antonio Ruiz Pipo } \\
\text { - Sofia Gubaidulina } \\
\text { - Tristan Murail } \\
\text { - Lennox Berkeley } \\
\text { - Reginald Smith Brindle } \\
\text { - Astor Piazzolla } \\
\text { - György Kurtág }\end{array}$ \\
\hline
\end{tabular}

Görsel 2. 1950 sonrası eser veren besteciler

\section{Latin Gitar Müziği}

- Agustin Barrios Mangore

- Antonio Lauro

- Jorge Morel

- Baden Powell

-Egberto Gismonti

- Paulo Bellinati

- Jaime Zenamon

- Maximo Diego Pujol

- Joao Pernambuoco

- Julio Sagreas

Görsel 3. Latin Gitar müziği bestecileri

Andres Segovia’nın haricinde, özellikle 19. yüzyılın son çeyreğinde Francisco Tarrega, 20. yüzyıl boyunca ise öğrencileri Emilio Pujol, Miguel Llobet ve Regino ile Eduardo Sainz de la Maza kardeşler İspanyol gitar müziğinin temsilcileri olarak gitar repertuvarına önemli katkılarda bulunmuşlardır. İspanyol gitar müziğinin genellenebilecek özellikleri, ABA formunda küçük çaplı dans formlarının kullanılması, bas tellerin açık çalınmasının getirdiği kolaylıkla, en fazla dört diyez ve iki bemol içeren tonların kullanılması ve eser içinde yapılan modülasyonların aynı adlı minör, majör tona veya IV., V. derece gibi sıradan tonal duraklar haricinde kullanılmaması olarak gösterilebilir. 
Segovia’nın gitar sahnesinde yer almasıyla, 1920 sonrasında yazılan gitar eserlerinin sayısında hızlı bir yükseliş olmuştur. Bu eserler daha önce de bahsedildiği gibi özellikle gitarist olmayan besteciler tarafından repertuvara kazandırılmıştır. 20. yüzyıl gitar müziğindeki gelişmelerle, diğer Batı müziği çalgılarının repertuvarına benzemeye başlayan yeni eserler verildiği söylenebilir. Farklı üsluplara ait bestecilik tekniklerinin kullanılmasıyla, gitar çalgısal sınırlarını aşmış, yöresel bir müzik aleti olmaktan çok, evrensel müziğin icra edilebildiği bir çalgıya dönüşmüştür.

\section{Francisco Tarrega Etkisi}

Tarrega’yı yalnızca İspanyol gitar müziğinin en önemli figürü olarak tanıtmak yeterli olmayacaktır. 1750 - 1850 yılları arasında oluşturulan gitar müziğini, teknik anlamda oldukça geliştirmiştir. Armonik ses kullanımı, sadece sol el kullanılarak yapılan legato ve tremolo gibi teknikleri eserlerinde ilk kullanan bestecidir. Gitar çalımı konusundaki tüm teknikleri isimlendiren ve çalıcılık anlamında kolaylıklar sağlayan teknik çalışmalarını bir araya getirdiği metoduyla kendisi ve öğrencilerinin “Tarrega Okulu” olarak anılmasını sağlamıştır. Eserlerinde görülen İspanyol müziği etkisi, o dönemde ortaya çıkan ulusalcılık akımının bir yansıması olarak görülebilir. Özellikle Frederic Chopin’in eserlerinde kullandığı Polonya halk müziği elementlerini Batı müziğine kazandırması neticesinde, bu etkiler Tarrega’nın müziğine de yansımıştır.

Bestelediği eserler genellikle ABA formunda ve Polka, Vals, Gavot, Mazurka ya da İspanyol folklorundan Jota gibi farklı dans özellikleri içeren yapılara sahiptir. Bunların yanı sıra yazdığı 35 Prelüdü ve Fantezi formundaki eserleriyle bestecinin Chopin’in ağıllıkla üzerinde durduğu müzikal formları kullanmaya çalıştığı görülebilir. Bu sebeple Tarrega’yı gitarın Chopin’i olarak tanımlamak yanlış olmayacaktır. Tarregảnın gerçekleştirdiği bir önemli yenilik ise Berlioz, Beethoven, Mozart, Chopin, Handel, Haydn, Wagner, Rossini, Verdi, Schubert, Schuman ve J. S. Bach’n eserlerini gitar için düzenlemesidir. Bilinen ilk Bach düzenlemesi Tarrega’ya aittir (Wade, 2012).

Görsel 4’te Tarrega’nın Marieta adlı bir mazurkası yer almaktadır. Görüleceği üzere eser iki bölmeli ve ilk bölme la minör tonunda, ikinci bölme ise aynı La majör tonda bestelenmiştir.

\section{Miguel Llobet Soles}

Segovia ile aynı dönemde yaşayan Llobet, Tarregảnın oluşturduğu gitar okulunu daha ileri taşıyarak uluslararası bir tanınırlık kazandırmıştır. Tarrega’nın aksine, Segovia gibi İspanya dışında birçok ülkede konser vermiştir. Segovia ile birlikte gitarın günümüzdeki yaygın popülerliğinin sorumlusu olarak görülmektedir (Purcell, 2004). Tarihte gerçekleştirilen ilk elektronik gitar ses kaydı Llobet’e aittir.

Llobet'in eserleri Tarrega’nın izlerini taşımaktadır. Hayatı boyunca bestelediği 75 eserin büyük bir çoğunluğu dans formundaki küçük çaplı eserlerden oluşmaktadır. En bilinen eserlerin- 


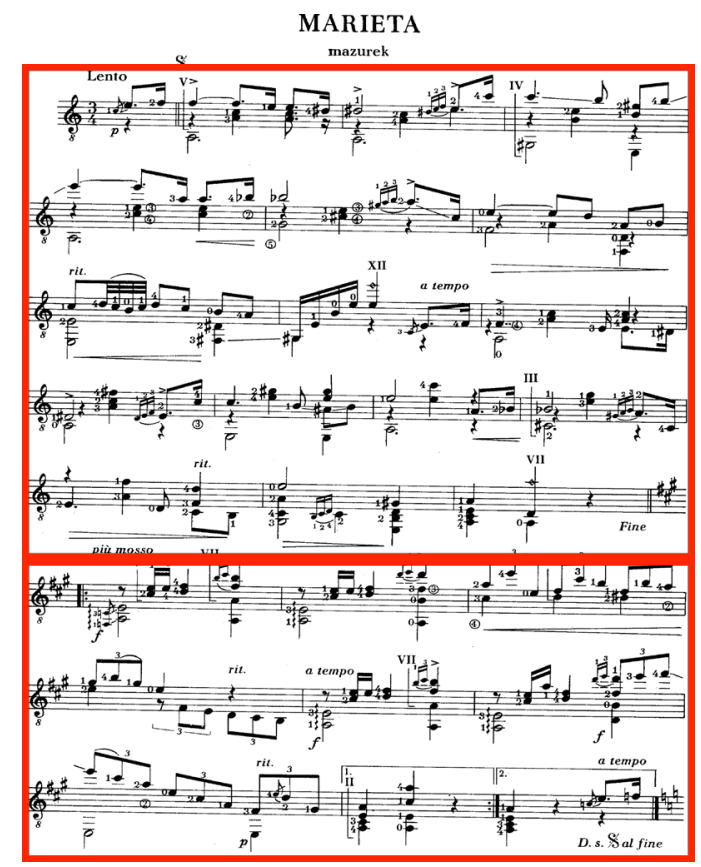

Görsel 4. Francisco Tarrega’nın Marieta - Mazurka isimli eseri

den biri olan "10 Popüler Katalan Şarkısı" albümünde, bölümler iki bölmeli formda ve Mi, Fa, La ve Re sesleri üzerinde minör ya da majör olarak bestelenmiştir.

Llobet, Tarrega’nın teknik buluşlarını eserlerinde sıkça kullanmış ve onların kullanım alanlarını çoğaltmıştır. Görsel 5, 6 ve 7'de görüleceği üzere, besteci Fernando Sor'un ünlü Folia teması üzerine bestelediği “Tema ve Varyasyonlar” adlı eserinin tema ve ilk iki varyasyonu üzerine kendi varyasyonlarını bestelemiştir. Bu varyasyonlardan bazıları Tarrega’nın geliştirdiği tekniklerin kullanılmasıyla oluşturulmuştur. Besteci 8. varyasyonda sadece armonik seslerin kullanımıyla oluşan bir stil kullanmıştır. 9. varyasyonda ise sadece sol elde seslerin legato çalınmasıyla oluşan bir pasaj görülmektedir. İlk olarak Tarrega’nın Gran Jota adlı eserinde kullandığı bu legato tekniğini daha da geliştirerek, tekniğin kullanım alanını genişletmiştir.

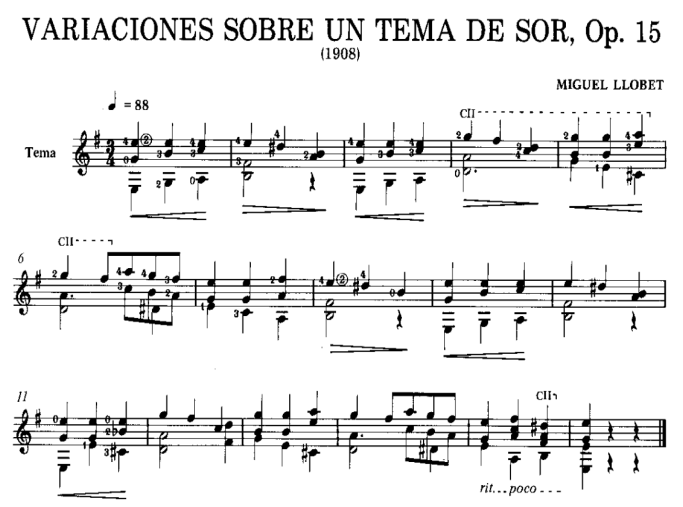

Görsel 5. Miguel Llobet'in Fernando Sor'un Teması Üzerine Varyasyonlar adlı eserinin teması 

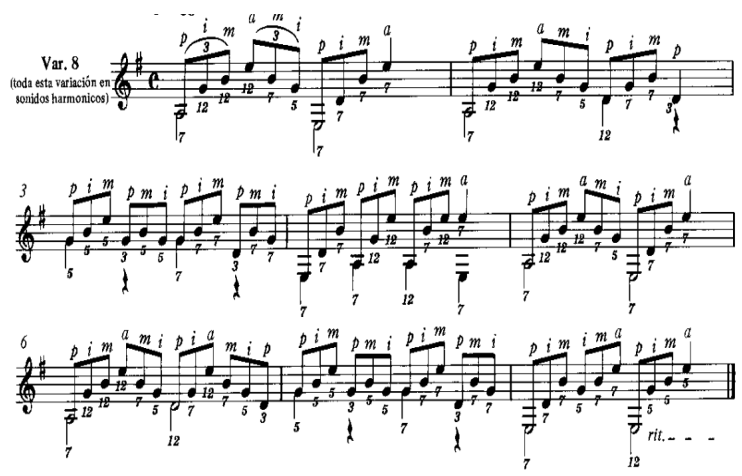

Görsel 6. Miguel Llobet'in Fernando Sor'un Teması Üzerine Varyasyonlar adlı eserinin 8. varyasyonu

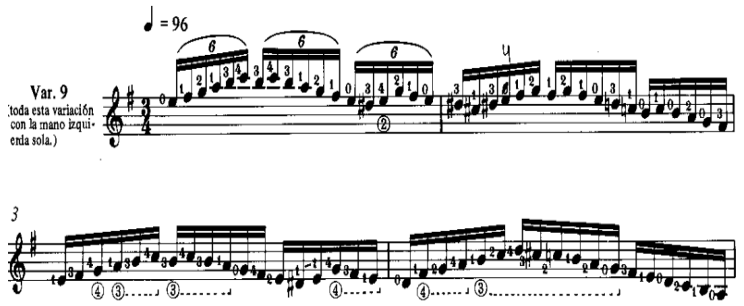

Görsel 7. Miguel Llobet'in Fernando Sor'un Teması Üzerine Varyasyonlar adlı eserinin 9. Varyasyonu

\section{Andres Segovia'ya İthaf Olarak Eser Yazan Besteciler ile Yeni Romantik Repertuvarın Ta- mamlanmasi}

Tarrega ve öğrencilerinin oluşturduğu, daha çok İspanyol folklor elementlerinden oluşan gitar repertuvarının aksine, Segovia daha önceki bölümlerde bahsedildiği gibi, gitarist olmayan bestecilerden yeni gitar repertuvarını oluşturma konusunda yardım istemiştir. Torroba, Ponce, Falla, Turina, Tedesco, Villa-Lobos, Rodrigo ve Tansman gibi besteciler bu bağlamda Segovia ile daimi bir iş birliği gerçekleştirmişlerdir. Bu yeni eserler, Tarrega okulunun oluşturduğu küçük çaplı eserler yerine, repertuvara büyük çaplı dans formları, üç bölümlü sonat ve gitar konçertosu gibi eserler olarak girmişlerdir. 1950'lere kadar bu besteciler tarafından gitar için 300'den fazla eser bestelenmiştir (Avraam, 1999).

Bestelenen eserler, gitarın diğer çalgılar karşısında eksik kaldığı Romantik Dönem repertuvarının geç de olsa 20. yüzyılda tamamlanmasını sağlamıştır. Yeni eserlerin romantik dönem müziği özellikleri taşımasının en önemli nedenlerinden biri bestecilerin kültürel elementleri müziklerinde kullanmalarıdır. 19. yüzyılda Chopin ve Lizst' in etkileriyle ortaya çıan ulusalcılık akımı kendilerinden sonra gelen bestecilerin müzikal kaynak seçiminde etkili olduğu düşünüldügünde, İspanyada Tarrega, Turina, Torroba ve Llobet, Meksika’da Ponce, Brezilya’da ise VillaLobos kendi ulusal müziklerinin gitar repertuvarına kazandırılmasını 20. yüzyılın ilk yarısında sağlamışlardır. Romantik gitar müziğinin gelişimindeki bu gecikme, Batı müziğindeki ortaya çıkışına göre 40 - 50 yıllık bir gecikme olarak görülebilir. 
Var olan Romantik Dönem eserleri açı̆̆ının kapatılmasıyla, Stravinski ve Schoenberg gibi bestecilerin 1910 sonrasında oluşturdukları ve 20. yüzyıl müziğini tanımlayan yeni akımlar, gitar müziğindeki bu gecikmeye bağlı olarak, 1950 sonrasında eser veren ve kurumsal bir eğitim alma fırsatını yakalayan gitarist bestecilerin müziklerinde kendisini göstermeye başlamıştır. $\mathrm{Bu}$ gitarist bestecilerin 20. yüzyıl müziğinin genel özelliklerini yansıtan ve kendi dönemlerinin akımlarından beslenerek yeni eserler besteledikleri söylenebilir.

\section{Federico Moreno Torroba}

Torroba, 20. yüzyıl gitar müziğinin en bilinen isimlerinin başında gelmektedir. 1918 yılında Segovia ile tanışmasından sonra gitar için bestelediği eserlerle uluslararası tanınırlığını gitar bestecisi olarak sağlamıştır. Gitar müziğinin yanı sıra, piyano ve İspanyol folklorunun önemli bir parçası olan ve hafif opera olarak tanımlanan "Zarzuela" formunda eserler vermiştir. Bestecilik özellikleri açısından dönemin avangart özelliklerini deneyimlemekle birlikte, tercihen lirik melodik yapıları tonal armoni çerçevesinde kullanmıştır. Zengin renk kullanımlarıyla bestelediği gitar müzikleri, İspanyol folklorik anlatımının şiirsel ve romantik hissiyatını sergilemektedir (Wade, 2007).

Görsel 8, 9 ve 10'da bestecinin gitar için yazdığı Sonatin adlı üç bölümlü sonat formundaki eserinin sonat allegrosu özelliğindeki ilk bölümü görülmektedir. 14. görselde eserin ana teması, 15. görselde yardımcı tema ve 16. görselde gelişme bölmesi sergilenmektedir. Klasik bir sonat allegrosu olarak, ana tema La majörde, yardımcı tema ise La majörün ilgili minörü olan Fa\# minörde verilmiştir. Eserin gelişme bölümünde, tematik yapı La Majörün ilgili dominantı olan Mi Majör yerine, Mi minörde verilmiş ve Re dominant 7'li akoruyla Sol Majöre yönelmiştir. Ana tonun 7. derecesi olan ve oldukça uzak sayılabilecek Sol sesine yapılan bu yönelim, eserin yazıldığı dönem öncesindeki eserlerde karşılaşılmayan bir özellik olarak ortaya çıkmaktadır.

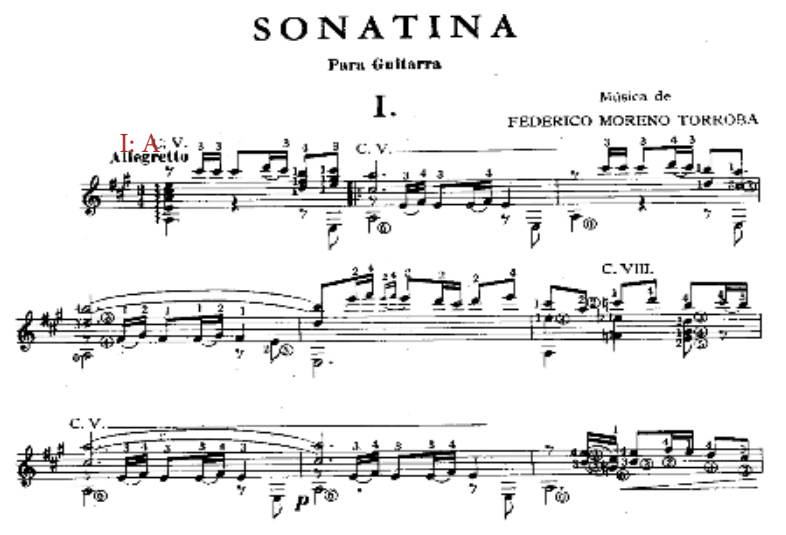

Görsel 8. Federico Moreno Torroba’nın Sonatina isimli eserinin ilk bölümü - ana tema 

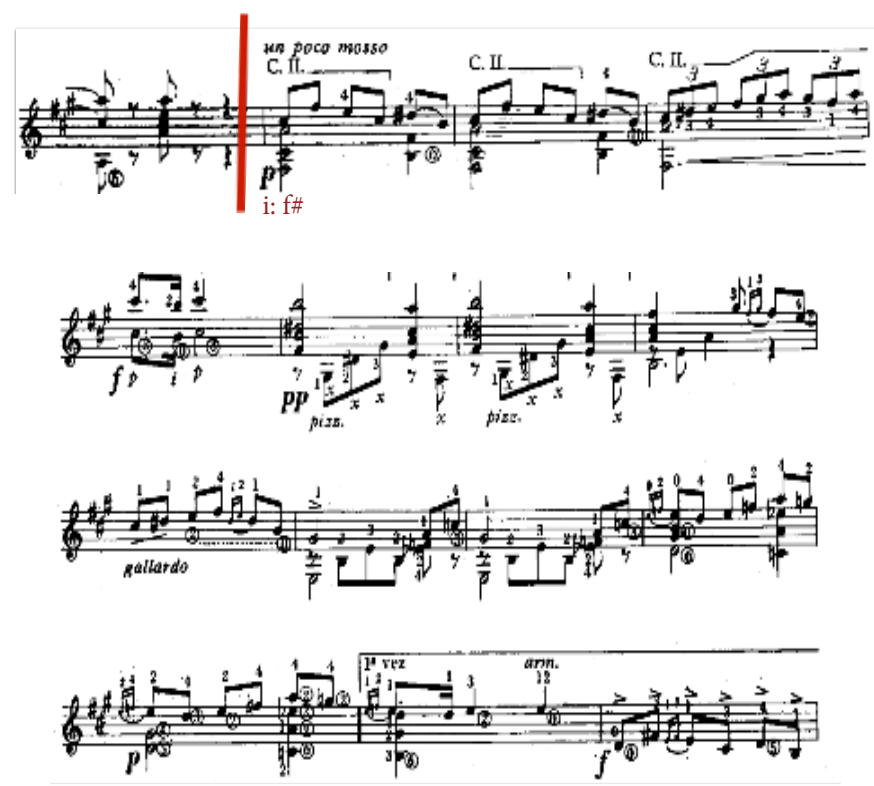

Görsel 9. Federico Moreno Torroba’nın Sonatina isimli eserinin ilk bölümü - yardımcı tema
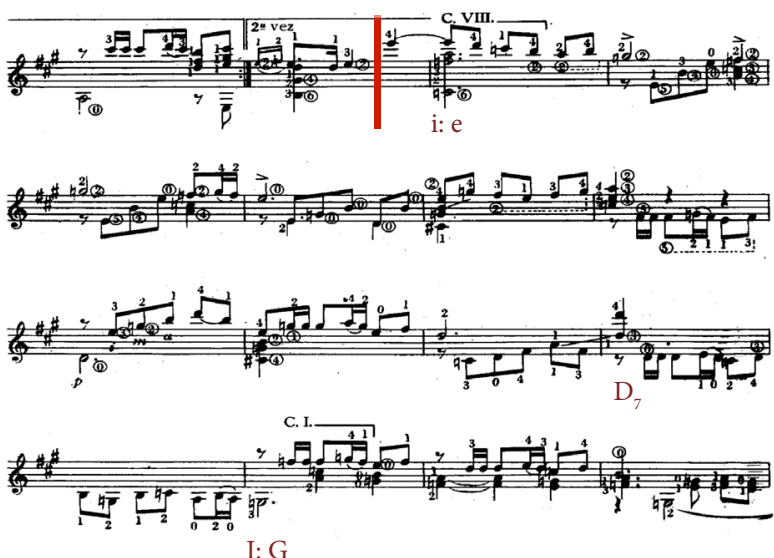

Görsel 10. Frederico Moreno Torroba’nın Sonatina İsimli Eserinin İlk Bölümü - Gelişme Bölümü

\section{Manuel Ponce}

Meksikalı besteci ve piyanist Ponce, Villa-Lobos’un Brezilya'da yaptığı gibi, müzik eğitimini İtalya ve Almanya'da tamamladıktan sonra ülkesine dönerek, kendi kültürünün Batı müziği kültürüyle kaynaştığı eserler vererek bir ekol yaratmış ve eğitmenliğini bu yönde sürdürmüştür. Özellikle küçük çaplı piyano eserleri ve duygusal içerikli halk melodileri besteleyen Ponce, müziğinde sofistike kontrpuan, izlenimci armoniler ve o dönemde yeni ortaya çıkan Latin Amerika ulusalcılığı akımının özelliklerini kullanmıştır (Long, 1999). 
Segovia ile tanışması sonrası gitar için birçok sonat, prelüd, süit ve varyasyon formunda eserler vermiştir. Bestecinin Concierto del Sur adlı bir de gitar konçertosu bulunmaktadır. Eserlerindeki bestecilik özellikleri nedeniyle Segovia Ponce hakkında "diğer besteciler (dönemin uluslararası ün kazanmış Batı müziği bestecileri) gibi yazabiliyor” diyerek, bestecinin eserlerinin, oluşturmaya çalıştığı yeni gitar repertuvarındaki önemini vurgulamak istemiştir (Long, 1999). Ponce’un bir başka özelliği ise özellikle lavta için eserler vermiş Sylvius Leopold Weiss, Allesandro Scarlatti gibi Barok Dönem bestecilerinin eserlerini imitasyon yoluyla kendi modern müziğiyle bir araya getirmesidir. The Suite in A minor, Prelude in E majör for Guitar and Harpsichord ve Balletto for Guitar adlı eserleri bu çalışmalarına örnek olarak gösterilebilir. The Suite in A minor adlı eserinde besteci geleneksel barok partita siralamasina uyarak Prelude, Allemande, Sarabande, Gavotte I ve II ve Gigue bölümlerinden oluşan bir süit bestelemiştir.

Ponce’un gitar için yazdığı sonat formundaki eserler, günümüz gitar repertuvarının teknik kabiliyet ve müzikalite açısından zorlayıcı eserleri olmakla birlikte hâlâ popülerliğini korumaktadır. Günümüzün yeni nesil gitaristleri Segovia’nın bıraktığı yorumlardan uzaklaşarak, bestecinin isteklerine ve eserin ihtiyacına uygun yorum çalışmaları yapmaktadırlar. Ponce’un farklı bestecilerin müzikal kimliklerini taklit edebilme yeteneği görsel 11'de verilen Romantic Sonata adlı eserinde de görülmektedir. Besteci Franz Schubert’e ithaf ettiği eserinde lirik melodileri uyumlu armoni ve gelişmiş modülasyonlarla birlikte kullanır.

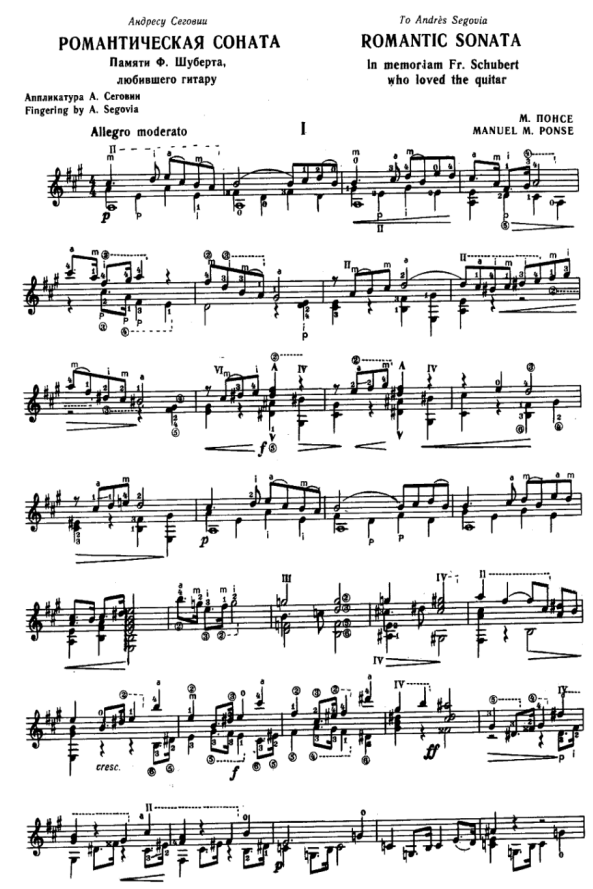

Görsel 11. Manuel Ponce’un Romantic Sonata isimli eserinin ilk bölümü, sayfa 1 


\section{Heitor Villa-Lobos}

Heitor Villa-Lobos'u üç dönemde incelemek doğru olacaktır: Sahip olduğu otodidakt eğitimle birlikte 1923’e kadar ülkesi Brezilya’yı gezerken duyduğu yerel form ve ezgileri müziklerinde kullandığı dönem, Arthur Rubinstein’ın genç Villa-Lobos'un solo piyano eserlerinden etkilenmesiyle bulunan sponsor desteğiyle 1923 - 1930 yılları arasında Paris’te müzik eğitimi aldığı ve eserlerinde Fransız müziği etkisinin baskın olduğu dönem, 1930'da ülkesi Brezilyayya dönerek, yerel müzik materyallerini Batı müziğinin armonik dili ve form yapılarıyla harmanladı̆̆ 1 dönem (Andreson, 2013).

1930 yılı sonrasında Brezilya’da ulusal müzik eğitiminden sorumlu kişi olması, hem ülkenin eğitiminde önemli katkılar yapmasını hem de kazandığı ün sayesinde kendi neslinin müzikal lideri olmasını sağlamıştır.

Villa-Lobos'un gitar için bestelediği eserlere bakıldığında, bestecinin Chopin'in piyano eserleriyle bir bağ kurduğunu görmek mümkün olacaktır. Brezilya müziğinin o dönemde önemli kültürel müzik formlarından biri olan "Choro" dans formunu, özellikle Chopin’in müziğinde görülen Mazurka, Vals, Polka gibi küçük çaplı formlarla birleştirmiştir. "Suite Populaire Bresilienne" adlı çalışmasının bölüm başlıkları şöyledir:

- I. Mazurka - Choro

- II. Schottish - Choro

- III. Valse - Choro

- IV. Gavota - Choro

- V. Chorinho

Chopin ile ilgili bir başka benzerlik ise, Segovia’nın gitar müziğine pedagojik anlamda katkı yapması için besteciye sipariş verdiği Douze Etudes çalısmasıdır. Gitar için günümüzde bile vazgeçilmez bir kaynak olarak kullanılan bu 12 etüt yapısal anlamda Chopin'in piyano için on ikişerli iki albüm olarak bestelediği etütlere bir gönderme olarak görülebilir.

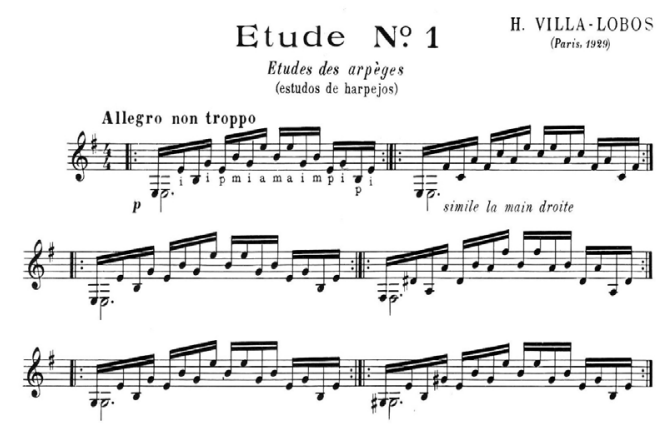

Görsel 12. Heitor Villa-Lobos’un Douze Etudes Çalışmasindan Etüt no.1 
Gitar için yazdığı 5 Preludes, Gitar Konçertosu, gitar ve şan için Bachianas Brasileiras no. 5 bestecinin Brezilya müziğinin ritmik ve melodik özelliklerini kullandığı diğer önemli eserleridir.

\section{Joaquin Rodrigo}

Joaquin Rodrigo, yeni klasikçi akımın önemli bir temsilcisidir. Kariyeri boyunca devaml1lığını koruyan müzikal dili, İspanyol halk müziği elementlerinin kullanımıyla zenginleşmiştir. Eserlerinde kullandığı dans formları 16. yüzyıl telli çalgı müziklerine göndermelerde bulunur (Wade, 2008). Görme engelli bir piyanist olarak hiç gitar eğitimi almamasına rağmen, kariyeri boyunca 25 kadar solo gitar eseri bestelemiştir. Her biri Alexandre Lagoya, Renato Tarrago, Angelo Gilardino, Sigfried Behrend ve Andres Segovia gibi dönemin önemli gitar yorumcularına ithaf edilmiş bu eserler, artistik özellikleriyle 19. yüzyıl İspanyol gitar müziğini modernleştirerek, gitarın İspanya kültüründeki etkin kimliğini yeniden yapılandırmıştır.

Ancak besteci solo gitar eserlerinden çok konçertolarıyla ve orkestra için bestelediği eserleriyle tanınmaktadır. Kariyeri boyunca, keman, çello, piyano, gitar ve arp için senfonik çapta eserler vermiştir. Solo gitar ve orkestra için üç, iki gitar ve orkestra için bir ve dört gitar ve orkestra için bir olmak üzere toplam beş gitar konçertosu bulunmaktadır.

Gitar müziğinin kült eserlerinin başında gelen Concierto de Aranjuez bestecinin 1939'da, Regino Sainz de la Maza’ya ithafen bestelediği ilk solo gitar konçertosudur. Hızlı - yavaş - hızlı sıralamasıyla konçerto üç bölümden oluşmaktadır. İlk bölüm geleneksel Flamenko özellikleri taşıyan, gitarın üç zamanlı ve iki zamanlı ritmik yapıların peşi sıra çalındığı, hemiola özellikli tematik unsurla başlar. Besteci, klasik konçertoların ilk bölüm - "Allegro" geleneğini bozarak, temayı önce gitarda seslendirir, sonra orkestra aracılığıyla tekrar eder. Solist çalgının orkestra ile birlikte çaldığı pasajlardan çok, solist - orkestra - solist - orkestra sıralamasıyla oluşturulan bir üslup benimsenmiştir. Bu üslup, Barok Dönem konçertolarındaki kompozisyon tekniklerini çağrıştırmaktadır.

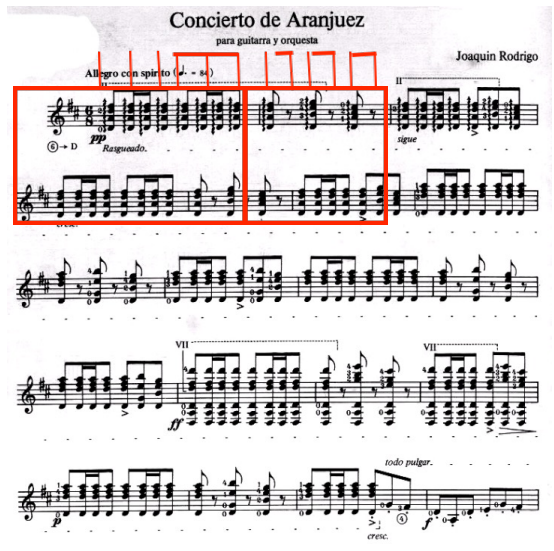

Görsel 13. Joaquin Rodrigo’nun Concierto de Aranjuez isimli konçertosunun birinci bölümü - ana tema 
Bölüm içindeki gitar pasajları, peşi sıra on altılık notalarla oluşturulmuş, Flamenko etkisi yaratan modal özellikli yapılardır (Görsel 14). Eserin tekniksel yapısı göz önünde bulundurulduğunda, artistik pasajlarıyla gitaristleri zorlayıcı bir eser olarak görülebilir. Bu özelliğinden dolayı, özellikle solist olarak kariyer yapan tüm gitaristlerin repertuvarında yer almaktadır.
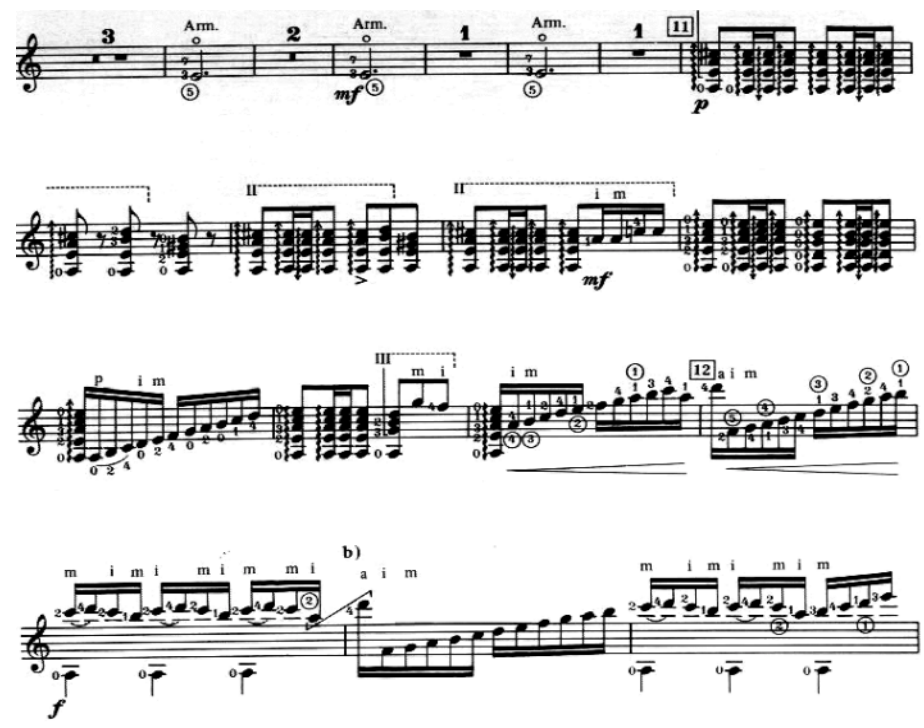

Görsel 14. Joaquin Rodrigo’nun Concierto de Aranjuez isimli konçertosunun birinci bölümü - gelișme bölmesi - modal pasaj yapiları

Aranjuez’in Segovia’ya ithaf edilmemesi ve Segovia’nın Rodrigo'ya tepki göstermesi üzerine gitar dünyasında dolaşan spekülatif söylemler mevcuttur. Rodrigo’nun Segovia’ya 1954 yllında ithaf ettiği ilk eser olan Tres Piezas Espanolas ve aynı yıl bestelediği ikinci ithaf eseri Fantasia Para un Gentilhombre (Bir beyefendi için Fantezi) solo gitar konçertosu, bölümlerinde tarihsel süreçte sıklıkla kullanılan İspanyol dans formlarının işlendiği diğer önemli eserlerdir. Fantasia Para un Gentilhombre 17. yüzyıl, İspanyol Barok gitar bestecisi Gaspar Sanz’n altı kısa dans parçası temel alınarak, yeni klasikçi üslupta dört bölümlü olarak bestelenmiştir. 


\section{SONUÇ}

Çalışmanın kapsadığg 30 yıllık süreçte, gitar müziği kompozisyonundaki kalıplaşmış bestecilik anlayışları, gitarist olmayan ve dönemlerinin başarılı bestecilerinin daha çok orkestra ağırlıklı kompozisyon tekniklerini gitar müziğine uyarlamalarıyla yeniden şekillendirilmiştir. $\mathrm{Bu}$ anlayış değişikliğinin bir nevi lideri olarak görülebilecek Andres Segovia, 1920 ve 1950 yılları arasında gerçekleştirdiği konser ve ses kayıtlarıyla bu bestecilerin eserlerini dünyaya tanıtmış ve gitar müziğinin kanıksanmış İspanyol Kültürü olma özelliğini, Meksikalı, İtalyan, Brezilyalı ve Polonyalı bestecilerin eserlerini seslendirerek, evrensel bir boyuta taşımıştır. Segoviảnın başarılı kariyerine paralel olarak, onun gitar dünyasındaki yenilenme çabalarına bestecilerin, dönemlerinin savaş nedenli kötü ekonomik koşullarından sıyrılmak ümidiyle sahip çıktığı fikri de göz önünde bulundurulabilir.

Klasik müziğin opera, senfonik eser, oda müziği ve solo çalgı müziği gibi farklı türlerine göre 19. Yüzyılda kompozisyon açısından önemli bir gelişim gösteremeyen gitarın, 20. yüzyılın ilk yarısında bu açığı kapattığı ve sanatsal akımları 40 -50 yıllık bir gecikmeyle de olsa takip etmeye başladığı söylenebilir.

Çalg1 üzerindeki algının değişmesiyle gitar, 19. yüzyılda, o dönemin şartlarında küçük çaplı ev konserleri ve eşlik çalgısı olarak kullanılırken, Andres Segoviảnın etkisi ile gitarist olmayan bestecilerin klasik müzik formlarını gitar müziğine taşımasıyla, büyük konser salonlarında kendisine yer bulan bir çalgıya dönüşmüştür.

1920 ve 1950 yılları arasında gerçekleşen niteliksel ve niceliksel bu gelişim, 300'e yakın solo gitar eserinin yanı sıra, neredeyse yüz yıla yakın bir zamandan sonra ilk gitar konçertosunun bestelenmesine, çalg1 eğitiminde diğer çalgılardaki pedagojik yaklaşımların gitar müziğine uyarlanmasına olanak sağlamıştır. . Francisco Tarrega ile başlayan klasik müzik mirasının önemli eserlerinin gitara uyarlanması fikri, 20. yüzyılın ilk yarısında büyük bir ivme kazanarak, gitar repertuvarına yeni bir alan oluşturmuştur. Gitarın dünya çapında yaygın olarak kullanılması, repertuvarda hem batı müziği formlarının ustaca kullanıldığı yeni eserler ortaya çıkmasına farklı folklorik materyallerin de gitar müziğine dâhil olmasında etkili olmuştur.

Bu bağlamda gitar repertuvarına yapılan katkıların 20. yüzyılın başından başlayarak özellikle 1960'larda besteci sayısı bazında da önemli bir niceliksel artış gösterdiği gözlenebilir. Bu artışın en önemli nedeni gitar eğitiminin kurumsallaşması sonrası yetişen yeni neslin, özellikle 20. yüzyıl müziği kompozisyon teknikleriyle yeni eserler vermeye başlaması ve gitarda yeni bir kulvar oluşturmasıdır. Gitar sahip olduğu renkler ve yeni teknik kullanım alanlarıyla sadece gitarist besteciler için değil aynı zamanda gitarist olmayan besteciler için de yeni keşfedilmiş bir kompozisyon aracına dönüşmüştür.

Kısaca 20. yüzyılın ikinci yarısına kadar geçen süreçte, klasik müzik alanında oluşan müzikal akımlarının ve bestecilik tekniklerinin gitar müziğine aktarılmasında ortaya çıkan zaman gecikmesinin, repertuvardaki yenilenme hareketi ve endirekt etkilerinden sonra giderek azaldığı gözlemlenebilir. Gitarın günümüz modern müziğinin kullanışlı bir çalgısı olarak görülmesinde bu sürecin katkısı göz ardı edilmemelidir. 


\section{KAYNAKÇA}

Andreson, K. (2013). Heitor Villa-Lobos (1887-1959).www.naxos.com, http://www.naxos.com/mainsite/blurbs_reviews. asp?item_code $=8.573115 \&$ cat Num $=573115$ \& filetype $=$ About\%20this\%20Recordingelanguage $=$ English \# (Erişim tarihi: 17.11.2015)

Avraam, V. (1999). The Starting of Andres Segovia's Career. Guiitarra Magazin,: http://www.guitarramagazine.com/andres_segovia_memory 558 (Erişim tarihi: 21.10.2015)

Long, R. (1999). Manuel Maria Ponce (1882-1948). www.naxos.com, http://www.naxos.com/mainsite/blurbs_reviews. asp?item_code $=8.554199 \&$ cat Num $=554199 \&$ filetype $=$ About\%20this\%20Recordingひlanguage $=$ English $\#$ (Erişim tarihi: 16.11.2015)

Purcell, R. (2004). Miguel Llobet. www.naxos.com, http://www.naxos.com/mainsite/blurbs_reviews.asp?item_code=8.557

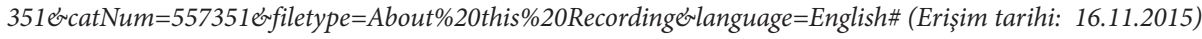

Wade, G. (2012). Johann Sebastian Bach (1685-1750) Guitar Transcriptions. www.naxos.com www.naxos.com/mainsite/ blurbs_reviews.asp?item_code $=8.572740 \&$ cat Num $=572740 \&$ filetype $=$ About\%20this\%20Recordingelanguage $=$ English (Erişim tarihi: 16.11.2015)

Wade, G. (2008). Joaquin Rodrigo (1901-1999). www.naxos.com http://www.naxos.com/mainsite/blurbs_reviews.

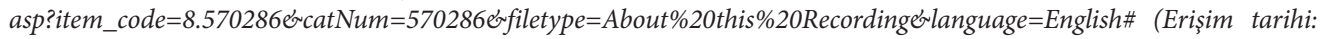
18.11.2015)

Wade, G. (2007). Federico Moreno Torroba (1891-1982). www.naxos.com, http://www.naxos.com/mainsite/blurbs_reviews.asp?item_code $=8.557902 \&$ catNum $=557902 \mho$ filetype $=$ About\%20this\%20Recordingelanguage $=$ English $\# \quad$ (Erişim tarihi: 16.11 .2015$)$

\section{Görsel Listesi}

Tablo 1. Klasik müziğin ve gitar müziğinin tarihsel süreçteki etkileşimleri

Görsel 1. 1950 öncesi eser veren besteciler

Görsel 2. 1950 sonrası eser veren besteciler

Görsel 3. Latin Gitar müziği bestecileri

Görsel 4. Francisco Tarrega’nın Marieta - Mazurka isimli eseri

Görsel 5. Miguel Llobet'in Fernando Sor’un Teması Üzerine Varyasyonlar adlı eserinin teması

Görsel 6. Miguel Llobet'in Fernando Sor'un Teması Üzerine Varyasyonlar adlı eserinin 8. Varyasyonu

Görsel 7. Miguel Llobet'in Fernando Sor’un Teması Üzerine Varyasyonlar adlı eserinin 9. Varyasyonu

Görsel 8. Federico Moreno Torroba’nın Sonatina isimli eserinin ilk bölümü - ana tema

Görsel 9. Federico Moreno Torroba’nın Sonatina isimli eserinin ilk bölümü - yardımcı tema

Görsel 10. Frederico Moreno Torroba’nın Sonatina İsimli Eserinin İlk Bölümü - Gelişme Bölümü

Görsel 11. Manuel Ponce’un Romantic Sonata isimli eserinin ilk bölümü, sayfa 1

Görsel 12. Heitor Villa-Lobos'un Douze Etudes Çalş̧masindan Etüt no.1

Görsel 13. Joaquin Rodrigo'nun Concierto de Aranjuez isimli konçertosunun birinci bölümü - ana tema

Görsel 14. Joaquin Rodrigónun Concierto de Aranjuez isimli konçertosunun birinci bölümü - gelişme bölmesi - modal pasaj yapıları 
